\title{
CLINICAL EVALUATION IN FEBRILE THROMBOCYTOPENIA IN ADOLESCENT
}

\author{
Sayeeda Afzal1, Jagadesh Prasad² \\ ${ }_{1}^{1}$ Assistant Professor, Department of Paediatrics, Vishwabharathi Medical College. \\ ${ }^{2}$ Senior Resident, Department of Paediatrics, Vishwabharathi Medical College.
}

\section{ABSTRACT}

\section{BACKGROUND}

Febrile thrombocytopenia is likely to differ according to the geographical areas. This is because some infections are endemic in certain geographical area. Therefore, a well-organised systematic approach that is carried out for fever with thrombocytopenia can shorten the duration of stay in hospital. We studied 100 adolescent patients of febrile thrombocytopenia.

\section{MATERIALS AND METHODS}

This study was done on patients, who were admitted in Kurnool Medical College, Kurnool. A prospective study of fever with thrombocytopenia was conducted. Patients of both sexes aged between 10 years and 19 years were included. Once the patients were admitted with fever in those who had thrombocytopenia, a careful history was recorded and general physical examination was done; specific and special investigations were done as and when indicated. The patient was said to have fever when A.M. temperature $>37.2$ degrees Celsius or P.M. temperature of $>37.7$ degrees Celsius was recorded. Thrombocytopenia was considered when patient had platelet count of less than 1,50,000/cu $\mathrm{mm}$. Once the specific diagnosis was reached, patients were treated and followup was done.

\section{RESULTS}

In our study of fever with thrombocytopenia, malaria (48\%) was the commonest cause followed by dengue fever (14\%) and enteric fever (8\%) among the diagnosed cases. However, undetermined febrile illness (29\%) constitute most number of cases.

\section{CONCLUSION}

Fever with thrombocytopenia is one of the most challenging problems in the field of Medicine. Fever with thrombocytopenia consists of occult presentations of common diseases rather than rare diseases. Infection is the commonest cause of fever with thrombocytopenia. Malaria, Typhoid and Dengue still present clinically in atypical and occult forms making diagnosis difficult and prolonged. So high index of clinical suspection is needed. In majority of patients, thrombocytopenia was transient and asymptomatic. Clinical manifestations of bleeding did correlate with severity of thrombocytopenia; lower platelet count had increased bleeding tendencies. It was observed that thrombocytopenia was rarely accompanied by bleeding.

\section{KEYWORDS}

Thrombocytopenia, Adolescent, Pancytopenia.

HOW TO CITE THIS ARTICLE: Afzal S, Prasad J. Clinical evaluation in febrile thrombocytopenia in adolescent. J. Evolution Med. Dent. Sci. 2017;6(1):36-41, DOI: 10.14260/Jemds/2017/11

\section{BACKGROUND}

Fever is a pervasive and ubiquitous theme in human myth, art and science. Fever is such a common manifestation of illness that it is not surprising to find accurate descriptions of the febrile patients in early-recorded history.[1] With the development of an effective thermometer by the Dutch instrument maker Daniel Gabrial Fahrenheit, in early eighteenth century new interest surfaced in the relationship between body temperature and disease. Fever is a common complaint, which brings the patient to the doctor.

Normal body temperature displays a diurnal pattern with lower values in the early morning hours and higher values in the evening. Normal ranges are between $35.8^{\circ} \mathrm{C}\left(96.5^{\circ} \mathrm{F}\right)$ and $37.2^{\circ} \mathrm{C}\left(99^{\circ} \mathrm{F}\right)$.

\section{Financial or Other, Competing Interest: None.}

Submission 26-11-2016, Peer Review 19-12-2016,

Acceptance 28-12-2016, Published 02-01-2017.

Corresponding Author:

Dr. Sayeeda Afzal,

H. No. 3/761/3,

Gaytri Estate, Kurnool.

E-mail: safu53@yahoo.co.in

DOI: $10.14260 /$ jemds $/ 2017 / 11$
Fever is superimposed on this pattern and thus temperatures are usually greatest in the afternoon and evening. Fever is defined as an elevation of the body temperature above the normal circadian range as the result of a change in the thermoregulatory center located in the anterior hypothalamus. An AM temperature of $>37.2^{\circ} \mathrm{C}$ $\left(98.9^{\circ} \mathrm{F}\right)$ or a P.M. temperature of $\left.>37.7^{\circ} \mathrm{C}(99)^{\circ} \mathrm{F}\right)$ would define fever.[1]

Thrombocytopenia is defined as platelet count < $150,000 / \mu \mathrm{L}$. This is due to decreased production, increased destruction (immunogenic and non-immunogenic), increased sequestration in spleen, of these infections is the commonest cause of thrombocytopenia.[2,3]

Adolescence has been defined as the period of life span between 10 - 19 years. Its formative period of life when maximum amount of physical, psychological and behavioural changes take place.[4]

The pattern of fever helps in differential diagnosis of fever. When fever is associated with localising signs and symptoms, it gives clue to the diagnosis. At times the fever course is prolonged and fever with thrombocytopenia narrows the differential diagnosis of the clinical entity.

Aetiologies of febrile thrombocytopenia are likely to differ according to the geographical areas. This is because some 
infections are endemic in certain geographical area. Seven to ten percent of malaria cases in India are found in Karnataka. Hassan, Tumkur, Chitradurga, Mandya, Raichur, Gulbarga, Mangalore and Bellary are endemic for malaria.[5]

In Karnataka Dengue fever is prevalent in areas like Bangalore, Bellary, Chikmagalur, Chitradurga, Haveri, Hassan, Shimoga and Tumkur.[6]

Leptospirosis endemic areas in Karnataka are Bangalore, Uttara Kannada, Dakshina Kannada, Shimoga, Udupi, Bidar and Gulbarga.[7]

In Andhra Pradesh malaria is found across the state, endemic malaria zone are Srikakulam, Vizianagaram, Vishakapatnam, Adilabad, Khammam and Northern Godavari district.

Dengue cases are found in large number in urban pockets [Hyderabad], Rayalaseema and Telangana Districts.

Septicaemia, infections like malaria, dengue fever, leptospirosis, typhoid, HIV and tuberculosis are some of the common causes of fever with thrombocytopenia. There are not many studies in the literature addressing this common clinical problem in adolescent.

Therefore, a well-organised systematic approach that is carried out with an awareness of causes of fever with thrombocytopenia can shorten the duration of investigations and bring out the diagnosis.

Hence, there is a need for a study to know the causes and complications of fever with thrombocytopenia.

\section{Objectives of Study}

1. To evaluate clinical profile of fever with thrombocytopenia.

2. To identify the cause of fever with thrombocytopenia.

3. To assess the clinical complications associated with fever and thrombocytopenia in adolescent.

\section{MATERIALS AND METHODS}

This study was done on patients, who were admitted in Kurnool Medical College, Kurnool.

A prospective study of ever with thrombocytopenia was conducted.

\section{Inclusion Criteria}

- Patients of both sexes aged between 10 years to 19 years.

- Patients admitted with fever and found to have thrombocytopenia are included in the study.

\section{Exclusion Criteria}

- Patients less than 10 yrs. and more than 19 yrs.

- Patients with fever and no thrombocytopenia.

- Patients with thrombocytopenia and no fever.

Once the patients were admitted with fever, in those who had thrombocytopenia, a careful history was recorded and general physical examination was done; specific and special investigations were done as and when indicated.

In whom a final definite diagnosis was reached, the disease was treated and in those who were affordable platelet count was repeated at the time of discharge and no effort was made to gather followup information, in case the patient was not followed up in our institution.
Details of history, general physical examination and laboratory investigation reports were noted down from time to time.

Once the specific diagnosis was reached, patients were treated for it specially and symptomatically (For ex: Platelet transfusion, Mechanical ventilations, Haemodialysis, etc.).

The patient was said to have fever when A.M. temperature $>37.2$ degrees Celsius or P.M. temperature of $>$ 37.7 degrees Celsius was recorded. ${ }^{[8]}$

Thrombocytopenia was considered when patient had platelet count of less than 1,50,000/cu mm. ${ }^{[9]}$

For bleeding complications, platelet transfusions were planned and also if platelet count was $<20,000 / \mathrm{cu} \mathrm{mm}$.

The causes of fever with thrombocytopenia are so numerous, so a simple workable classification is presented:

1. Viral Causes - CMV; Dengue; Parvo-B19; HSV, HIV, Hanta, etc.

2. Bacterial Causes - Gram +ve and -ve septicaemia, tuberculosis, leptospira, typhoid, etc.

3. Protozoal - Malaria.

4. Others - Leukaemia, Lymphoma, etc.

Investigations included in Diagnosis of Cases of Fever with Thrombocytopenia

Malaria

Thick and Thin smear. Thick blood smears are more sensitive in detecting malarial parasites, because the blood is more concentrated allowing for a greater volume of blood to be examined.[10]

\section{Dengue}

IgM and IgG ELISA. Sensitivity $96.5-100 \%$ and specificity 96 - 98.5\% (Mac-Elisa PanBio).

\section{Leptospirosis}

IgM Elisa. Sensitivity 96.5 - 100\% and specificity 96 - 98.5\%. (Mac-Elisa PanBio). This test was done only in patients from endemic areas.

\section{Widal Test}

The titre cut-off for 0 agglutinins varied from 1:20 to 1:80 by tube dilution technique or 1:160 or higher by slide agglutination technique with sensitivity of $61 \%, 64 \%$ and $72.5 \%$. The specificity ranges between 5 to $92 \%$.[11]

\section{Other Tests}

Liver function tests, Renal function tests, Urine examination and Ultrasonography of the abdomen.

\section{RESULTS AND OBSERVATIONS}

A total of 100 cases with fever with thrombocytopenia admitted at Kurnool Medical College were studied.

Out of 100 cases, total number of Males were 51 and Females were 49.

\begin{tabular}{|c|c|c|}
\hline Age Group (yrs.) & No. of Patients & $\%$ \\
\hline $10-12$ & 22 & 22 \\
\hline $12-14$ & 28 & 28 \\
\hline $14-16$ & 20 & 20 \\
\hline $16-19$ & 30 & 30 \\
\hline Table 1. Age Distribution of Patients Studied \\
\hline \multicolumn{2}{|l}{} \\
\hline
\end{tabular}




\begin{tabular}{|c|c|c|}
\hline Gender & Number of Patients & $\%$ \\
\hline Male & 51 & 51.0 \\
\hline Female & 49 & 49.0 \\
\hline Total & 100 & 100.0 \\
\hline
\end{tabular}

\section{Thrombocytopenia}

Of the 100 cases with thrombocytopenia, 80 cases (80\%) had platelets between 50,000 to $1,50,000,13$ cases $(13 \%)$ had platelets between 20,000 and 50,000 and 7 cases (7\%) had platelets below 20,000. Clinical manifestations of thrombocytopenia were noted in 18 cases. However, clinical manifestations and thrombocytopenia did not correlate in all cases.

\section{Bleeding Manifestations}

Out of 100 cases, 18 cases had thrombocytopenia signs; 8 cases had manifestations of multiple bleeding manifestations (in the form of petechiae/epistaxis/rash/haematemesis); 3 cases had petechiae, 4 cases had rash, 1 case had haematuria; 2 cases had epistaxis.

\begin{tabular}{|c|c|c|c|}
\hline Platelet & Total Number & Bleeding Tendencies \\
\cline { 3 - 4 } Count & of Patients & No & Yes \\
\hline$<20000$ & $7(7 \%)$ & $2(2.4 \%)$ & $5(27 \%)$ \\
\hline $20000-50000$ & $13(13 \%)$ & $7(8.5 \%)$ & $6(33.3 \%)$ \\
\hline $50000-100000$ & $43(43 \%)$ & $38(46.3 \%)$ & $5(27.8 \%)$ \\
\hline$>100000$ & $37(37 \%)$ & $35(42.7 \%)$ & $2(11.1 \%)$ \\
\hline Total & $\mathbf{1 0 0 ( 1 0 0 \% )}$ & $\mathbf{8 2 ( 1 0 0 \% )}$ & $\mathbf{1 8 ( 1 0 0 \% )}$ \\
\hline \multirow{4}{*}{ Inference } & $\begin{array}{c}\text { Lower platelet counts is significantly } \\
\text { associated with bleeding tendencies with P } \\
<0.001\end{array}$ \\
\hline \multicolumn{3}{|c|}{ Table 3. Correlation of Platelet } \\
Count with Bleeding Tendencies \\
\hline
\end{tabular}

\section{Causes of Fever with Thrombocytopenia}

Out of 100 cases definitive diagnosis was established in 71 cases, remaining 29 cases were categorised as undetermined febrile illness as definitive diagnosis could not be achieved with available relevant investigations.

\begin{tabular}{|c|c|c|}
\hline $\begin{array}{c}\text { Causes of Fever with } \\
\text { Thrombocytopenia }\end{array}$ & Number of Cases & Percentage \\
\hline Malaria & 48 cases & $48 \%$ \\
\hline Dengue Fever & 14 cases & $14 \%$ \\
\hline Enteric Fever & 2 cases & $2 \%$ \\
\hline $\begin{array}{c}\text { Undetermined Febrile } \\
\text { Illness }\end{array}$ & 29 cases & $29 \%$ \\
\hline Septicaemia & 6 cases & $6 \%$ \\
\hline HIV & 1 case & $1 \%$ \\
\hline \multicolumn{2}{|c|}{ Table 4. Causes of Fever with Thrombocytopenia } \\
\hline
\end{tabular}

\section{Malaria}

Malaria has been diagnosed in 48 cases, Vivax malaria in 30 cases, falciparum in 14 cases, 4 cases had mixed infections with Vivax and falciparum.

2 cases of malaria went into sepsis.

\begin{tabular}{|c|c|c|}
\hline Type of Malaria & Number of Cases & Percentage \\
\hline Vivax & 30 & $62.5 \%$ \\
\hline Falciparum & 14 & $29.16 \%$ \\
\hline Mixed & 4 & $8.33 \%$ \\
\hline \multicolumn{3}{|c|}{ Table 5. Malaria Types } \\
\hline
\end{tabular}

\section{Dengue Fever}

Dengue fever was diagnosed in 14 cases, of these 2 cases of dengue showed features of polyserositis. IgG antibodies in 2, IgM in 2, both IgG and IgM in 10 cases.

\begin{tabular}{|c|c|c|}
\hline Dengue & Number of Patients (n = 100) & \% \\
\hline Nil & 86 & 86.0 \\
\hline Present & 14 & 14.0 \\
\hline IgG/M+ & 10 & 10.0 \\
\hline IgG+ & 2 & 2.0 \\
\hline IgM+ & 2 & 2.0 \\
\hline \multicolumn{2}{|c|}{ Table 6. Distribution of Dengue of Patients Studied } \\
\hline
\end{tabular}

\section{Severe Sepsis}

Severe sepsis was diagnosed in 6 cases, of these 2 cases were secondary to malaria, 1 case was due to dengue, 2 cases were due to pneumonia and 1 case was secondary to undetermined febrile illness category.

\begin{tabular}{|c|c|c|}
\hline Methodology of Sepsis & Number of Cases & Percentage \\
\hline Malaria & 2 & $33.33 \%$ \\
\hline Dengue & 1 & $16.66 \%$ \\
\hline Pneumonia & 2 & $33.33 \%$ \\
\hline $\begin{array}{c}\text { Undetermined Febrile } \\
\text { Illness }\end{array}$ & 1 & $16.66 \%$ \\
\hline \multicolumn{2}{|c|}{$\begin{array}{c}\text { Table 7. Table showing Aetiologies } \\
\text { of Severe Sepsis in this Study }\end{array}$} \\
\hline
\end{tabular}

\section{Enteric Fever}

Enteric fever was diagnosed in 2 cases, 1 had agglutination titres of $1: 320$ and remaining 1 case had 1:160. Both the cases had features suggestive of hepatitis in association with enteric fever.

\section{Hepatitis}

Twelve cases had hepatitis, 5 cases were due to malaria, 2 cases was due to enteric fever and 5 cases were secondary to undetermined febrile illness (V).

\begin{tabular}{|c|c|c|}
\hline Malaria (M) & 5 cases & $41.66 \%$ \\
\hline Dengue Fever (E) & 2 cases & $16.66 \%$ \\
\hline Undetermined Febrile Illness (V) & 5 cases & $41.66 \%$ \\
\hline \multicolumn{2}{|c|}{ Table 8. Incidence of Hepatitis in Fever with } \\
Thrombocytopenia Cases in this Study \\
\hline
\end{tabular}

\section{Polyserositis}

Six cases of severe sepsis showed polyserositis, two cases were secondary to Dengue and four cases were secondary to undetermined Febrile illness.

\begin{tabular}{|c|c|c|}
\hline Undetermined Febrile Illness (UVFI) & 4 & $66.66 \%$ \\
\hline Dengue Fever & 2 & $33.33 \%$ \\
\hline \multicolumn{2}{|c|}{ Table 9. Polyserositis in Relation } \\
to Fever with Thrombocytopenia \\
\hline
\end{tabular}

\section{Acute Kidney Injury}

Six cases of severe sepsis had acute kidney injury, one was due to undetermined febrile illness and three were due to severe malaria and two due to pneumonia.

\begin{tabular}{|c|c|c|}
\hline Undetermined Febrile Illness (UVFI) & 1 & $16.66 \%$ \\
\hline Malaria & 3 & $50 \%$ \\
\hline Pneumonia & 2 & $33.33 \%$ \\
\hline
\end{tabular}


Study of Anaemia in Relation to Fever with Thrombocytopenia

- 41 cases were having anaemia.

- 21 cases were showing microcytic hypochromic anaemia.

- 3 had dimorphic anaemia.

- 4 macrocytic blood picture.

- 12 showed normochromic normocytic anaemia.

- 1 was having pancytopenia.

- Out of 48 malaria cases, 11 had anaemia, 1 case was having pancytopenia secondary to Vivax. Rest others with anaemia were due to Vivax in 4 cases, 3 due to falciparum and 3 had mixed infections.

\begin{tabular}{|c|c|c|}
\hline Pancytopenia (P) & 1 & $2.43 \%$ \\
\hline Dimorphic (D) & 3 & $7.31 \%$ \\
\hline Macrocytic (M) & 4 & $9.75 \%$ \\
\hline Normocytic Normochromic (N) & 12 & $29.26 \%$ \\
\hline Microcytic (MH) & 21 & $51.21 \%$ \\
\hline \multicolumn{3}{|c|}{$\begin{array}{l}\text { Table 11. Types of Anaemia in Relation } \\
\text { to Fever with Thrombocytopenia }\end{array}$} \\
\hline
\end{tabular}

\begin{tabular}{|c|c|c|}
\hline Outcome & Number of Patients & $\%$ \\
\hline Improved & 90 & 90.0 \\
\hline Against medical advise & 7 & 7.0 \\
\hline Death & 3 & 3.0 \\
\hline Total & 100 & 100.0 \\
\hline
\end{tabular}

\section{Mortality}

Three cases succumbed to the disease and all were diagnosed with severe sepsis.

\begin{tabular}{|c|c|c|}
\hline Falciparum Malaria & 2 & $66.66 \%$ \\
\hline Pneumonia (p) & 1 & $33.33 \%$ \\
\hline \multicolumn{2}{|c|}{ Table 13. Causes of Mortality in } \\
Fever with Thrombocytopenia \\
\hline
\end{tabular}

\section{DISCUSSION}

In our study of fever with thrombocytopenia, malaria (48\%) was the commonest cause followed by dengue fever $(14 \%)$ and enteric fever (8\%) among the diagnosed cases. However, undetermined febrile illness (29\%) constitute the most number of cases.

There are not many studies done in children, especially in adolescent so we compared our work with different adult study in Asia.

A study was conducted by Nair PS, Jain A, Kumar V and Khanduri U. (200) at St. Stephen's Hospital, New Delhi, for a period of one and a half years. A total of 109 cases $(76$ males, 33 females) were studied with the same criteria as in our study.[12] Septicaemia with 29 cases was the leading cause of fever with thrombocytopenia. Second common cause was enteric fever (16) followed by dengue (15), megaloblastic anaemia (13), malaria (10), haematological malignancy (4) cases.[12]

In our study, $80 \%$ cases had platelets in range of 50,000 to $1,50,000$. Platelet counts between 20,000 and 50,000 was seen in $13 \%$ cases. $7 \%$ cases had platelet count below 20,000 . In Nair's study, out of 109 cases 62 cases (56.8\%) had platelet count between 50,000 to $1,00,000,28$ cases $(25.7 \%)$ had counts between 20,000 and 50,000 .

In our study, bleeding manifestations were seen in 18 cases $(18 \%)$. Spontaneous bleeding was seen in 7 cases (38.88\%).

In Nair's study, out of 109 patients 45 had thrombocytopenia signs accounting for $41.3 \%$. Out of 45 cases, spontaneous bleeding was seen in 31 cases accounting for $69 \%$ bleeding manifestations.[12]

During the course of Hospital stay, platelets showed increasing trends in 90 cases (90\%).

In our study, forty one cases (41\%) were having anaemia among which 21 cases were having Microcytic Hypochromic anaemia. In Nair's study haematological condition accounted for $15 \%$ cases.

In our study, severe sepsis accounted for $6 \%$ cases of fever with thrombocytopenia. In Nair's study, septicaemia seen in 29 cases was the leading cause of fever with thrombocytopenia.

In our study, malaria was found to be the commonest cause $(48 \%)$. In other study, malaria was the fifth common cause $(9.2 \%)$.

A study conducted at NIMS, Abbottabad, Pakistan showed that $70 \%$ of malaria cases had thrombocytopenia. Mild thrombocytopenia $(50.000-1,50,000)$ in $48.4 \%$, moderate thrombocytopenia $(20,000-50,000)$ in $16.4 \%$ and severe thrombocytopenia $(<20,000)$ in $5.2 \%$ cases.[13]

In our study enteric fever accounted for $2 \%$, whereas in other study it accounted to $14.7 \%$. In a study conducted at Kuala Lumpur, Malaysia, it was found that $32 \%$ cases of typhoid had a platelet count below 1,00,000. The cause for thrombocytopenia remained uncertain, but may be due to septicaemia during initial period of infection or due to disseminated intravascular coagulation.[14]

Dengue constituted $14 \%$ in our study and $13.8 \%$ in other study.

\begin{tabular}{|c|c|c|}
\hline Disease Category & $\begin{array}{c}\text { Nair's Study } \\
\text { (n=109) No. of } \\
\text { Cases with } \\
\text { Percentage }\end{array}$ & $\begin{array}{c}\text { Present Study } \\
\text { (n=100) No. of } \\
\text { Cases with } \\
\text { Percentage }\end{array}$ \\
\hline Malaria & 10 cases $(9.2 \%)$ & 48 cases $(48 \%)$ \\
\hline Enteric Fever & 16 cases $(14.7 \%)$ & 2 cases $(2 \%)$ \\
\hline Dengue Fever & 15 cases $(13.8 \%)$ & 14 cases $(14 \%)$ \\
\hline Sepsis & 29 cases $(26.6 \%$ & 6 cases $(6 \%)$ \\
\hline HIV & 0 & 1 case $(1 \%)$ \\
\hline $\begin{array}{c}\text { Haematological } \\
\text { Condition }\end{array}$ & 17 cases $(15.6 \%)$ & 41 cases $(41 \%)$ \\
\hline Others & 20 cases $(18.3 \%)$ & $\begin{array}{c}29 \% \text { undetermined } \\
\text { febrile illness }\end{array}$ \\
\hline Table 14. Comparison of Present Study with \\
Nair Study with Respect to Disease Category
\end{tabular}

(\#Haematological condition was not the primary diagnosis and it included anaemia).

In our study petechiae/purpura (61.11\%) was the commonest bleeding manifestations followed by spontaneous bleeding (38.88\%). In other study, spontaneous bleeding was 
the commonest bleeding manifestation $(68 \%)$ followed by petechiae/purpura accounting for $(22.22 \%)$.

In our study $80 \%$ cases had platelets in the range of 50000 of 150,000 , whereas other study had platelets in the range 50,000 to 100,000 in $56.8 \%$.

In our study, platelets in 20000 to 50000 were in $13 \%$ and in other study it was $25.7 \%$.

During the course of treatment in our study $90 \%$ clinically improved and $10 \%$ had decreasing trend, among which 3 cases died. In other study, $7.3 \%$ cases had decreasing platelet trend.

In conclusion, malaria accounted for majority cases of fever with thrombocytopenia. Platelets improved with definite management of underlying infection. Sepsis accounted for major cause of mortality.

Many cases of fever with thrombocytopenia are due to undetermined febrile illness and among detected cases of malaria, dengue, enteric fever and severe sepsis secondary to other causes are major cases.

The difference in the study can be attributed to various reasons. Nair's study was done in New Delhi and our study at Kurnool, Andhra Pradesh, hence endemicity of disease vary. Other causes may be due to seasonal and regional variation. The sensitivity and specificity of tests vary. The diagnosis also alters, especially in those cases which have been partially treated and referred.

\begin{tabular}{|c|c|c|}
\hline $\begin{array}{c}\text { Thrombocytopenia } \\
\text { Signs }\end{array}$ & $\begin{array}{c}\text { Nair's Study No. } \\
\text { of Cases with } \\
\text { Percentage }\end{array}$ & $\begin{array}{c}\text { Present Study } \\
\text { No. of Cases with } \\
\text { Percentage }\end{array}$ \\
\hline Present & 45 cases $(41.3 \%)$ & 18 cases $(18 \%)$ \\
\hline Absent & 64 cases $(58.7 \%)$ & 82 cases $(82 \%)$ \\
\hline
\end{tabular}

Table 15. Comparison of Present Study with Nair's Study with Respect to Thrombocytopenia Signs

\begin{tabular}{|c|c|c|}
\hline $\begin{array}{c}\text { Bleeding } \\
\text { Manifestations }\end{array}$ & $\begin{array}{c}\text { Nair's Study No. } \\
\text { of Cases with } \\
\text { Percentage }\end{array}$ & $\begin{array}{c}\text { Present Study } \\
\text { No. of Cases with } \\
\text { Percentage }\end{array}$ \\
\hline Petechiae/Purpura & 10 cases $(22.22 \%)$ & 11 cases $(61.11 \%)$ \\
\hline $\begin{array}{c}\text { Spontaneous } \\
\text { Bleeding }\end{array}$ & 31 cases (68\%) & 7 cases (38.88\%) \\
\hline $\begin{array}{c}\text { Table 16. Comparison of Present Study with Nair's } \\
\text { Study with Respect to Bleeding Manifestations }\end{array}$ \\
\hline
\end{tabular}

Clinical manifestations of thrombocytopenia in febrile thrombocytopenia happens in only $18 \%$ cases in our study. In Nair's study, $41.3 \%$ had bleeding manifestations. It is vital to check platelet count universally in all patients with fever to narrow down the differential diagnosis.

\begin{tabular}{|c|c|c|}
\hline Platelet Count & $\begin{array}{c}\text { Nair's Study No. } \\
\text { of Cases with } \\
\text { Percentage }\end{array}$ & $\begin{array}{c}\text { Present Study No. } \\
\text { of Cases with } \\
\text { Percentage }\end{array}$ \\
\hline $50,000-1,50,000$ & 62 cases $(56.8 \%)$ & 80 cases $(80 \%)$ \\
\hline $20,000-50,000$ & 28 cases $(25.7 \%)$ & 13 cases $(13 \%)$ \\
\hline$<20,000$ & 19 cases $(17.5 \%)$ & 7 cases $(7 \%)$ \\
\hline Table 17. Comparison of Present Study with Nair's \\
Study with Respect to Platelet Count \\
\hline
\end{tabular}

Thrombocytopenia is a common finding in malaria, about $80 \%$ of malaria have the same. ${ }^{[15,16]}$

It was observed that thrombocytopenia was rarely accompanied by bleeding and DIC both in our study and Nair study. Platelet count can fall below 25,000, but uncommon.[16]

Platelet count increases in malaria cases as effective treatment is initiated; hence, there is no need for platelet transfusion.[16]

The prevalence of thrombocytopenia was $78.4 \%$ in malaria cases. Thrombocytopenia was found in $40 \%$ to $90 \%$ cases infected with falciparum. ${ }^{[16]}$

The mechanism for thrombocytopenia was either peripheral destruction or platelet consumption by DIC.[15,16]

Profound thrombocytopenia $<5000$ has been reported in Indian literature in a 43 years female with Vivax malaria.[15]

\section{CONCLUSION}

Fever with thrombocytopenia is one of the most challenging problems in the field of Medicine.

Fever with thrombocytopenia consists of occult presentations of common diseases rather than rare diseases. Anaemia was found in a significant number of cases $(41 \%$ cases) in our study.

Infection is the commonest cause of fever with thrombocytopenia. Among infections, malaria was the commonest cause. This was followed by dengue fever and enteric fever. Many febrile illness cases were of undetermined aetiology.

Malaria, typhoid and dengue are still present clinically in atypical and occult forms making diagnosis difficult and prolonged. So high index of clinical suspicion is needed. In our study, $22.91 \%$ of cases of malaria also had associated anaemia.

So, they should be investigated with some routine and specific tests like rapid spot test IgM Elisa for Dengue and Leptospira antibodies, etc.

In majority of patients, thrombocytopenia was transient and asymptomatic.

Clinical manifestations of bleeding did correlate with severity of thrombocytopenia; lower platelet count had increased bleeding tendencies.

However, any patient with fever irrespective of presence of bleeding manifestations should be evaluated for thrombocytopenia.

Some patients with platelet count of 10,000 or less did not have any bleeding manifestations. Spontaneous bleeding patients should be evaluated for disseminated intravascular coagulation also.

Platelet count improved rapidly with treatment of antimalarial drugs. Twelve percent of the cases irrespective of the primary diagnosis develop hepatitis.

A major share (29\%) remained undiagnosed by the relevant available investigations and hence were grouped under the broad category of undetermined febrile illness.

Majority of the cases under febrile illness of undetermined aetiology had signs and symptoms suggestive of Dengue fever/malaria, but the diagnosis could not be correlated with the serology.

Hence, there is a need for better investigations with higher sensitivity and specificity and to detect newer viral 
strains, which may be the cause for these febrile illnesses of undetermined aetiology.

\section{REFERENCES}

[1] Woodward TE. The fever pattern as a diagnostic aid. In: Mackowiack PA, ed. Fever, basic mechanisms and management. $2^{\text {nd }}$ edn. Philadephia: Lippincott Raven 1997:215-35.

[2] Reyhan DK, Francia CG, Jose AL. Thrombocytopenia. In: Itchman MA, Kipps TJ, Kawshanky K, et al, eds. Williams haematology. $7^{\text {th }}$ edn. USA: McGraw Hill 2006:p. 1749.

[3] Handian RI. Bleeding and thrombosis. In: Braunwald E, Facui AS, Kasper DL, eds Harrison principles of internal medicine. $15^{\text {th }}$ edn. Vol. 1. USA: Mc Graw Hill 2001:p. 358.

[4] World Health Organisation. Young people's health - a challenge for society report of study group on Young People and Health for All by the year 2000. Technical Report Series, No.731, Geneva: World Health Organisation 1986.

[5] www.mrcindia.org/ivdc-profile.

[6] ICMR annual report, 2005-2006, 54.

[7] Shivakumar S. Medicine update. 2008;18:799-809.

[8] Charles AD, Reuven P. Fever and hyperthermia. In: Dan L, Dennis L, Larry J, et al, eds. Harrison's textbook of principles of internal medicine. $18^{\text {th }}$ edn. Vol. 1. McGraw-Hill Inc 2012:p. 143.
[9] Barbara K. Disorders of platelets and vessel wall. In: Dan L, Dennis L, Larry J, et al, eds. Harrison's text book of principles of internal medicine. $18^{\text {th }}$ edn. McGrawHill Inc 2012:965-6.

[10] CDC treatment guidelines, treatment of malaria (guidelines for clinical) April 2011.

[11] Thelma ET, Roxanne LA, Myrna TM, et al. Clinical application of the widal test. J Microbiol Infect Dis 1991;20(1):23-6.

[12] Nair PS, Jain A, Khanduri U, et al. A study of feverassociated thrombocytopenia. JAPI 2003;51:1173.

[13] Hayat AS, Shaikh N, Siddiqui MS, et al. Thrombocytopenia: frequency and degree in patients with falciparum malaria. Professional Med J 2011;18(1):75-9.

[14] Yap PK, Chua CT. The haemogram in the diagnosis of acute typhoid fever--with special reference to thrombocytopenia. Singapore Med J 1983;24(3):1613.

[15] Kakar A, Bhoi S, Prakash V, et al. Profound thrombocytopenia in plasmodium vivax malaria. Diagn Microbiol Infect Dis 1999;35(3):243-4.

[16] Jadhav UM, Patkar VS, Kadam NN. Thrombocytopenia in malaria--correlation with type and severity of malaria. J Assoc Physician India 2004;52:615-8. 